\title{
EKSPEKTASI RENCANA MASA DEPAN MAHASISWA PROGRAM PENDIDIKAN KEPANITERAAN DOKTER (P3D) TAHAP DUA FAKULTAS KEDOKTERAN UNIVERSITAS PADJADJARAN ANGKATAN 2000-2001
}

\author{
Sharon Gondodiputro, Henni Djuhaeni, Guswan Wiwaha \\ Bagian Ilmu Kesehatan Masyarakat, Fakultas Kedokteran \\ Universitas Padjadjaran, Bandung
}

\begin{abstract}
ABSTRAK
Kebutuhan dokter untuk memenuhi pelayanan kesehatan primer di Jawa Barat sangat besar. Untuk itu Fakultas Kedokteran Universitas Padjadjaran (FKUP) yang terletak di Provinsi Jawa Barat mempunyai kontribusi yang besar dalam pemenuhan dokter. Kajian ini bertujuan mendapatkan gambaran ekspektasi lokasi dan tempat bekerja lulusan dokter FKUP yang dapat digunakan untuk pengembangan kurikulum sehingga memenuhi kebutuhan (need) pelayanan kedokteran dan kesehatan di masyarakat. Metode yang digunakan adalah cross sectional dengan subjek 156 peserta didik P3D tahap dua Angkatan 2000 - 2001 FK Unpad. Data dikumpulkan melalui angket/kuesioner kemudian dilakukan analisis deskriptif menggunakan distribusi frekuensi. Hasil kajian adalah kontribusi FK Unpad dalam menyumbangkan sumber daya manusia di sarana pelayanan kesehatan primer bagi Jawa Barat hanya 30 $40 \%$. Sebagian besar $(75,64 \%)$ peserta akan bekerja terlebih dahulu, namun selanjutnya sebagian besar $(97,46 \%)$ akan melanjutkan pendidikan spesialisasi $(81,69 \%)$. Hal ini menunjukkan bahwa peserta tidak berminat, bekerja hanya sementara di pelayanan primer sehingga mengakibatkan masalah besar dalam kesinambungan program kesehatan serta inefektif dan inefisiensi dana untuk pelatihan. Spesialisasi yang paling diminati adalah 4 bidang utama yaitu ilmu penyakit dalam, ilmu bedah, ilmu kesehatan anak dan ilmu kebidanan. Di pihak lain magister rumah sakit menjadi peminatan dengan proporsi terbesar diikuti dengan magister kesehatan masyarakat, hukum kesehatan, dan Ekonomi kesehatan. Kesimpulan: Fakultas Kedokteran Unpad perlu memberikan prioritas kepada calon mahasiswa yang berasal dari Jawa Barat agar dapat berkontribusi dalam memenuhi kebutuhan dokter di Jawa Barat dan perlu pengembangan kurikulum pendidikan dokter agar lebih menarik, sehingga para calon dokter ini bersedia untuk tetap bekerja di sarana pelayanan kesehatan primer.
\end{abstract}

Kata kunci: Peserta didik, pelayanan kesehatan primer, pelayanan kesehatan sekunder, pendidikan spesialisasi, pendidikan magister, kedokteran keluarga

\section{FUTURE PLAN OF FINAL SEMESTER MEDICAL STUDENTS, FACULTY OF MEDICINE UNIVERSITY PADJADJARAN YEAR 2000-2001}

\begin{abstract}
The need of doctors which worked at the primary health centers in West Java was high. Faculty of Medicine Universitas Padjadjaran (FKUP) had the responsibility to fulfill the scarcity of doctors in West Java. The aim of this study was to know the expectation of work location of medical doctors " to be "so that the faculty could develop the medical education currículum that fulfill the community needs. This study was a cross sectional study with 156 final semester medical students year $2000-2001$, using questionnaire and analyzed by frequency distribution. The results were the contribution of FKUP to fulfill the health workforce in West Java is only $30-40 \%$.Most of the students planned to work first $(75.64 \%)$, but after that, most of them $(97.46 \%)$ planned to continue their study especially for specialization (81.69\%). This situation had an negative impact on the continuity of health programs for the community (primary care), because there would be always new doctors who would work at the primary health centres. The most interested specializations were internal medicine, surgery, pediatrics, obstetric-gynaecology. On the other hand, students who chose master program, were interested to study hospital administration/management and health management, health law and health economics. The reasons they wanted to work first were mostly to get experiences $(35.18 \%)$ and to collect money for further study $(32.16 \%)$. Most of the respondents planned to work at primary health center $26.72 \%$ mostly puskesmas and secondary health center (20.61\%). Other choices were working at Industries and Non Governmental Organizations.
\end{abstract}

Alamat Korespondensi:

dr. Sharon Gondodiputro

Bagian IImu Kesehatan Masyarakat, Fakultas Kedokteran

Universitas Padjadjaran, Bandung

Jl. Jatinangor Sumedang, Gedung A3 lantai 1, Telp.0811234624

Email: sharon_gondodiputro@yahoo.com 
Conclusions: FKUP gives more opportunity for students from West Java studying at FKUP so that in the future they could fulfill the scarcity of doctors in West Java. Secondly medical curriculum must be developed so that the doctors "to be" are more interested to work at the primary health centers permanently.

Key words: Final semester medical students, primary health center, secondary health center specialization, master program

\section{PENDAHULUAN}

Derajat kesehatan di Indonesia tidak merata dan cenderung menurun. Angka kematian ibu dan angka kematian bayi sebagai indikator Indeks Pembangunan Manusia (IPM) menurun landai dan masih menjadi masalah. Beban ini ditambah dengan timbulnya penyakit menular yang baru dan yang lama (new emerging dan re-emerging diseases), sementara penyakit tidak menular atau degeneratif mulai meningkat (non communicable disease). ${ }^{1}$ Hal ini tentu saja menjadi masukan bagi Fakultas Kedokteran untuk mengembangkan kurikulum demi memenuhi kebutuhan pelayanan kedokteran dan kesehatan di masyarakat.

Dengan telah dikeluarkannya Kurikulum Inti Pendidikan Dokter Indonesia tahun 2004 dan disahkannya Standar Kompetensi Dokter Indonesia oleh Konsil Kedokteran Indonesia tahun 2006, maka semakin jelas arah pendidikan dokter di Indonesia yaitu menghasilkan dokter yang bekerja di layanan primer dengan pendekatan kedokteran keluarga. ${ }^{2,3}$ Dengan pendekatan ini diharapkan seorang dokter umum tidak hanya mementingkan upaya kuratif saja, tetapi lebih fokus kepada upaya preventif dan promotif, karena status sehat dan sakit merupakan keadaan yang sangat dinamis, suatu saat seseorang dapat menjadi sakit, saat yang lain dia menjadi sehat. Hal ini berimplikasi bahwa untuk menjadi sehat tidak hanya dapat diselesaikan dengan pengobatan saja, tetapi merupakan proses yang kontinu dan dikenal dengan nama health enhancement continuum. ${ }^{4}$

Pemerintah Provinsi Jawa Barat melalui Peraturan Daerah No. 1 tahun 2001 telah menetapkan visi pembangunannya, yaitu Jawa Barat dengan iman \& taqwa sebagai provinsi termaju dan mitra terdepan ibukota negara tahun 2010, dengan indikator utama indeks pembangunan manusia 80 . Berdasarkan pengamatan selama 3 tahun (2001-2003) menunjukkan bahwa pencapaian visi ini tidak optimal sehingga dibuat 'visi tambahan' Focal Concern Visi 2003-2008, yaitu akselerasi peningkatan kesejahteraan masyarakat guna mendukung pencapaian visi Jawa Barat 2010 dengan strategi program yaitu: 1) Akses dan kualitas pelayanan kesehatan terutama keluarga miskin; 2) Sumber daya kesehatan; 3) Pemberdayaan masyarakat, dan 4) Pembiayaan kesehatan.

Jumlah dokter yang bekerja di sarana pelayanan kesehatan primer di Jawa Barat adalah 2.280 dokter (1:18.194) dengan penye- baran yang tidak merata. ${ }^{5}$ Masih ada puskesmas yang tidak mempunyai dokter seperti di Kabupaten Tasikmalaya dan Kabupaten Ciamis.

Dengan keadaan seperti yang dijelaskan di atas, maka Fakultas Kedokteran Universitas Padjadjaran yang berada di wilayah pemerintahan Provinsi Jawa Barat, seyogianya turut berkontribusi dalam pemenuhan sumber daya manusia (health workforce).

Agar dapat berkontribusi secara maksimal, diperlukan suatu studi untuk mendapatkan gambaran rencana masa depan lulusan dokter Fakultas Kedokteran Universitas Padjadjaran sebagai salah satu masukan/pertimbangan dalam pemenuhan kebutuhan sumberdaya kesehatan di Jawa Barat.

\section{METODE}

Metode yang dilakukan adalah studi deskriptif secara cross-sectional terhadap peserta program pendidikan profesi dokter tahap II/magang dokter muda Fakultas Kedokteran Universitas Padjadjaran sebanyak 156 orang (total populasi) dengan menggunakan angket/kuesioner. Selanjutnya data dikumpulkan, diolah, dan dianalisis menggunakan distribusi frekuensi berdasarkan jenis kelamin.

\section{HASIL}

Hasil pengamatan terhadap daerah asal peserta pendidikan menunjukkan bahwa hanya 44,87\% yang berasal dari provinsi Jawa Barat dan Banten dan 30,13\% di antaranya berasal dari kota Bandung. Sisanya $(19,87 \%)$ berasal dari Sumatera, Jawa Tengah sebesar $5,13 \%$ serta lain-lain seperti Kalimantan dan Jawa Timur hanya sebesar $1,28 \%$.

Pengamatan selanjutnya dilakukan terhadap rencana kegiatan peserta didik setelah lulus dari Fakultas Kedokteran Universitas Padjadjaran. Hasil pengamatan menunjukkan bahwa sebagian besar $(75,64 \%)$ peserta pendidikan setelah lulus berencana untuk langsung bekerja, baru kemudian 97,46\% di antaranya akan melanjutkan pendidikan. Sementara peserta pendidikan yang memiliki rencana untuk melanjutkan ke jenjang selanjutnya setelah lulus nanti sebanyak 23,72\%. (Gambar 1).

Pendidikan yang dituju setelah lulus menjadi dokter dapat dilihat pada Gambar 2 . Bagi peserta yang berencana langsung melan- 
jutkan pendidikan setelah lulus dokter, sebagian besar (90,24\%; 90\% laki-laki dan 90,48\% perempuan) memilih pendidikan spesialisasi daripada pendidikan magister yang hanya sebesar $9,76 \%$ (laki-laki 10\%, perempuan 9,76\%). Begitu pula peserta didik yang akan bekerja terlebih dahulu kemudian melanjutkan pendidikan, ternyata sebagian besar $81,69 \%$ (laki-laki $78 \%$, perempuan $83,7 \%$ ) memilih pendidikan spesialisasi daripada pendidikan magister $(18,31 \%)$. Namun demikian terjadi peningkatan 2 kali peminatan untuk pendidikan magister bagi peserta didik yang langsung melanjutkan pendidikan dibandingkan bagi peserta didik yang bekerja terlebih dahulu kemudian melanjutkan pendidikan.

Pendidikan spesialisasi yang diminati oleh peserta didik baik yang akan langsung

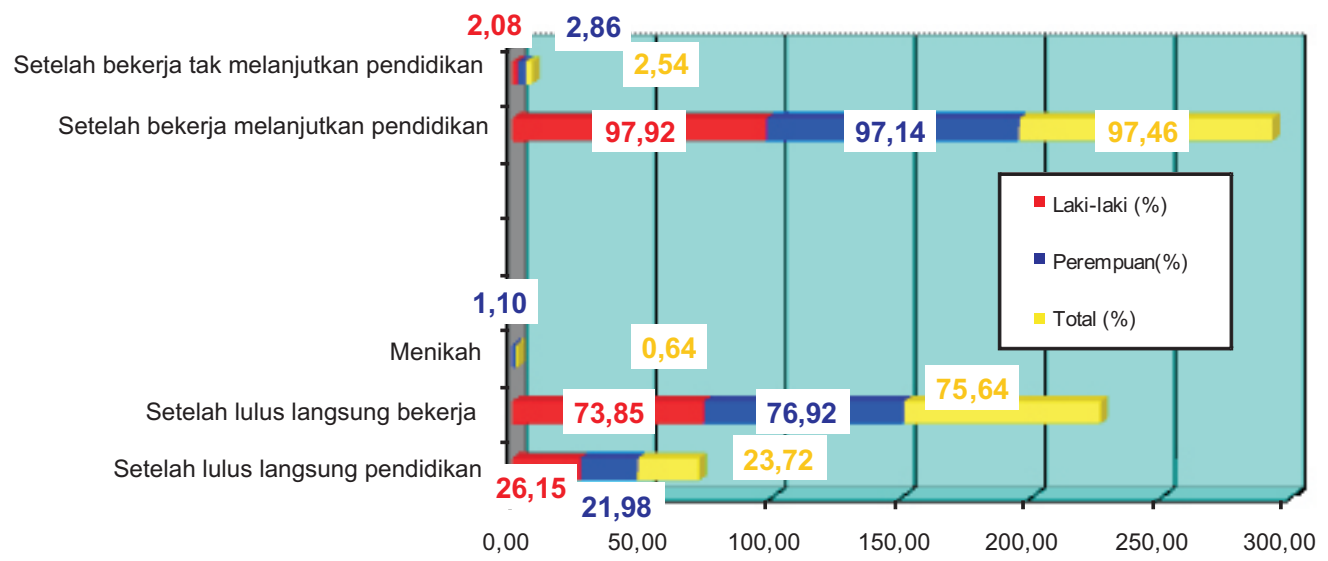

Gambar 1 Proporsi Rencana Melanjutkan Pendidikan atau Bekerja Setelah Lulus Dokter Peserta Didik P3D Tahap 2 Fakultas Kedokteran Unpad Tahun 2007

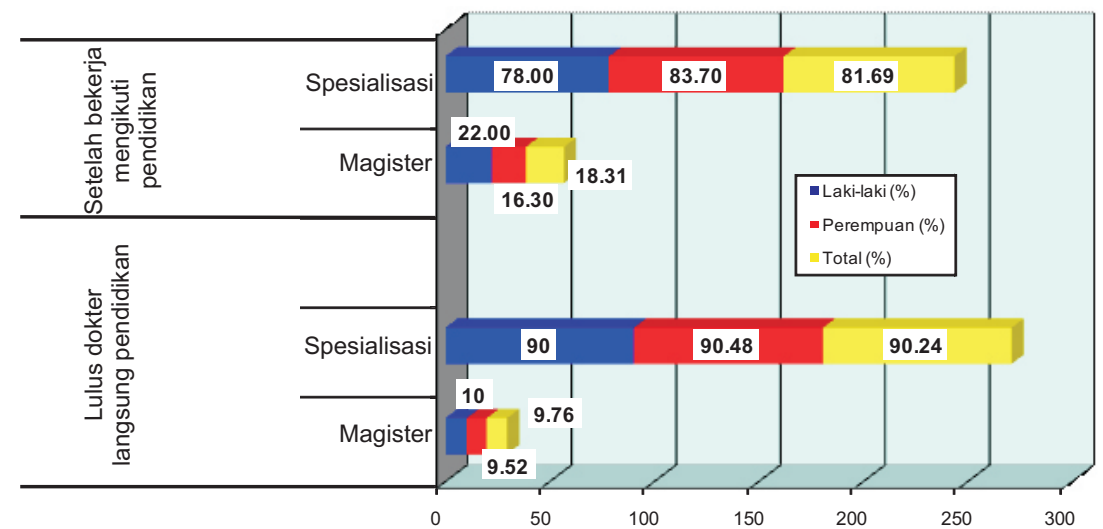

\section{Gambar 2 Proporsi Rencana Melanjutkan Pendidikan Peserta Didik P3D Tahap 2 Fakultas} Kedokteran Unpad Tahun 2007

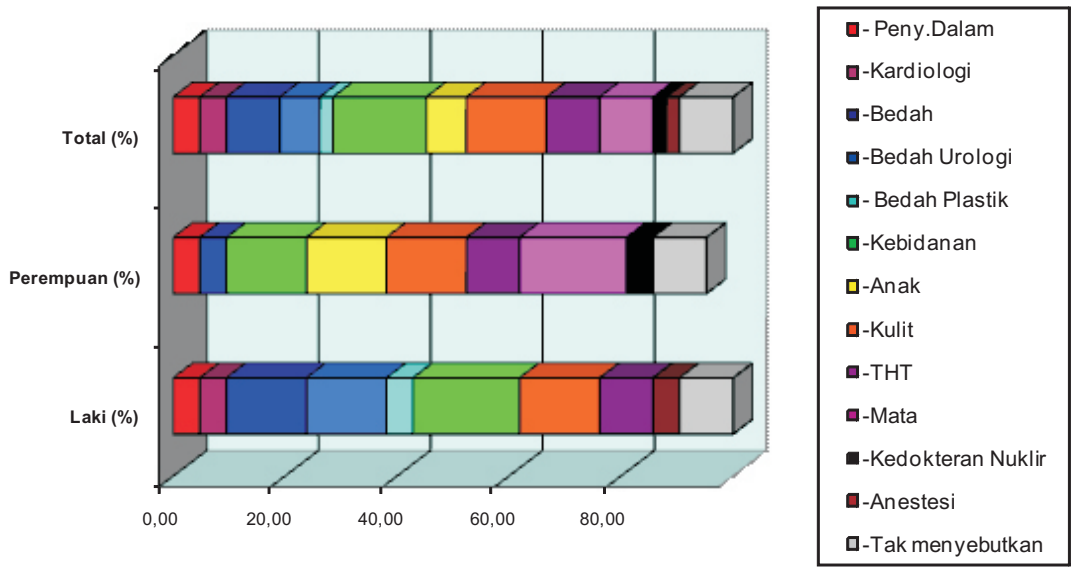

Gambar 3 Proporsi Rencana Pendidikan Spesialisasi yang Langsung Melanjutkan Pendidikan Bagi Peserta Didik P3D Tahap 2 Fakultas Kedokteran Unpad Tahun 2007 
melanjutkan pendidikan maupun yang bekerja terlebih dahulu, sebagian besar masih mencakup empat bidang utama yaitu ilmu penyakit dalam, ilmu bedah, ilmu kesehatan anak dan ilmu kebidanan seperti yang terlihat pada Gambar 3.

Pada Gambar 3 tersebut terlihat pula bahwa pada kelompok laki-laki selain ke-4 bidang utama tersebut, mereka juga berminat untuk melanjutkan pendidikan spesialisasi di bidang kulit dan kelamin. Hal ini kemungkinan besar terjadi dengan makin berkembangnya ilmu kosmetik. Pada kelompok perempuan selain juga meminati pendidikan spesialisasi di bidang kulit dan kelamin, mereka meminati pula bidang ilmu kesehatan mata.

Untuk bidang-bidang lain seperti spe- sialisasi rehabilitasi medik, ilmu kesehatan jiwa sepertinya mereka tidak berminat, padahal bidang spesialisasi ini sangat dibutuhkan di Indonesia.

Untuk pendidikan magister yang diminati adalah seperti yang terlihat pada Gambar 4. Magister rumah sakit menjadi peminatan dengan proporsi terbesar baik di kelompok perempuan maupun laki-laki, diikuti dengan magister kesehatan. Hal yang menarik adalah timbulnya peminatan peserta didik diberbagai ilmu sosial seperti manajemen, manajemen kesehatan, manajemen kesehatan masyarakat, hukum kesehatan, dan ekonomi kesehatan. Informasi ini penting untuk pengembangan pendidikan magister di Fakultas Kedokteran Unpad, sehingga di masa-masa yang akan datang dapat

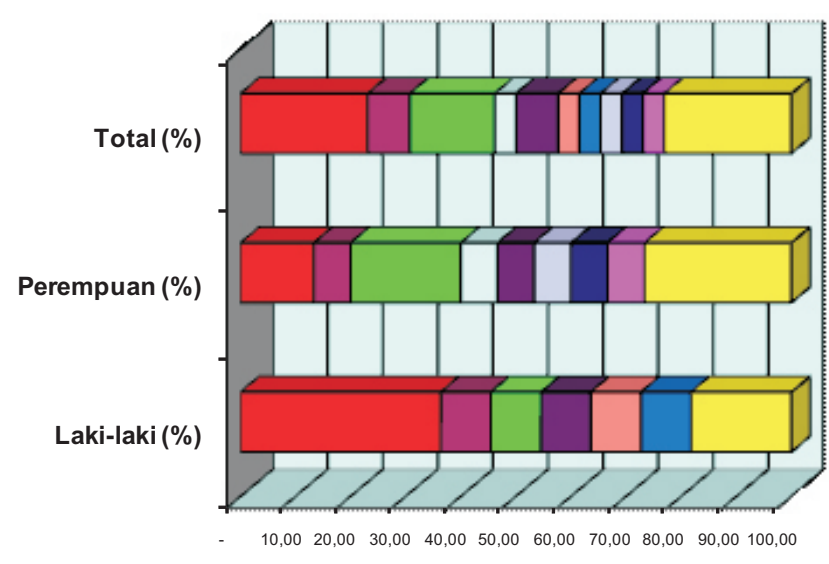

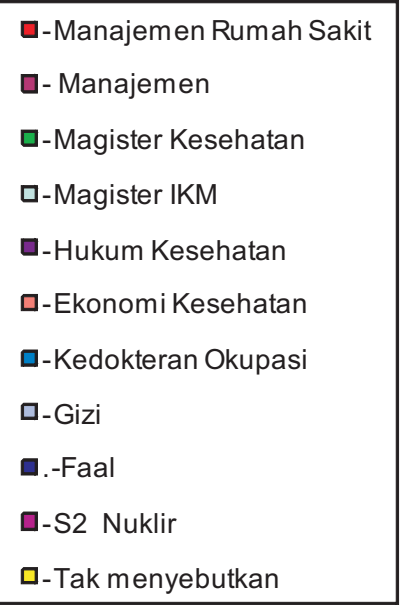

\section{Gambar 4 Proporsi Rencana Pendidikan Megister Setelah Bekerja Bagi Peserta Didik P3D Tahap 2 Fakultas Kedokteran Unpad Tahun 2007}

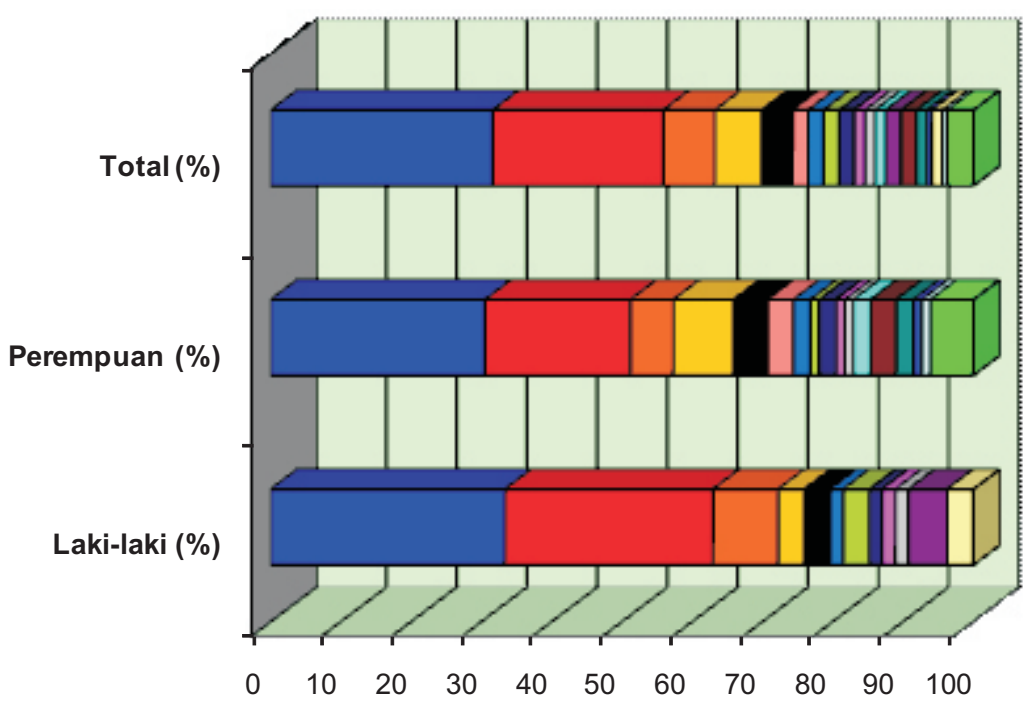

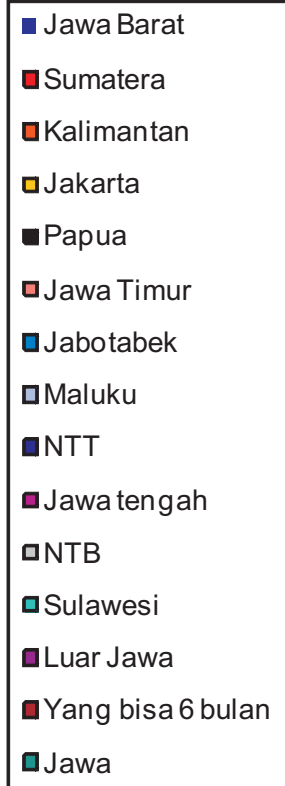

Gambar 5 Proporsi Rencana Tujuan Daerah Tempat Bekerja Setelah Lulus Dokter Bagi Peserta Didik P3D Tahap 2 Fakultas Kedokteran Unpad Tahun 2007 


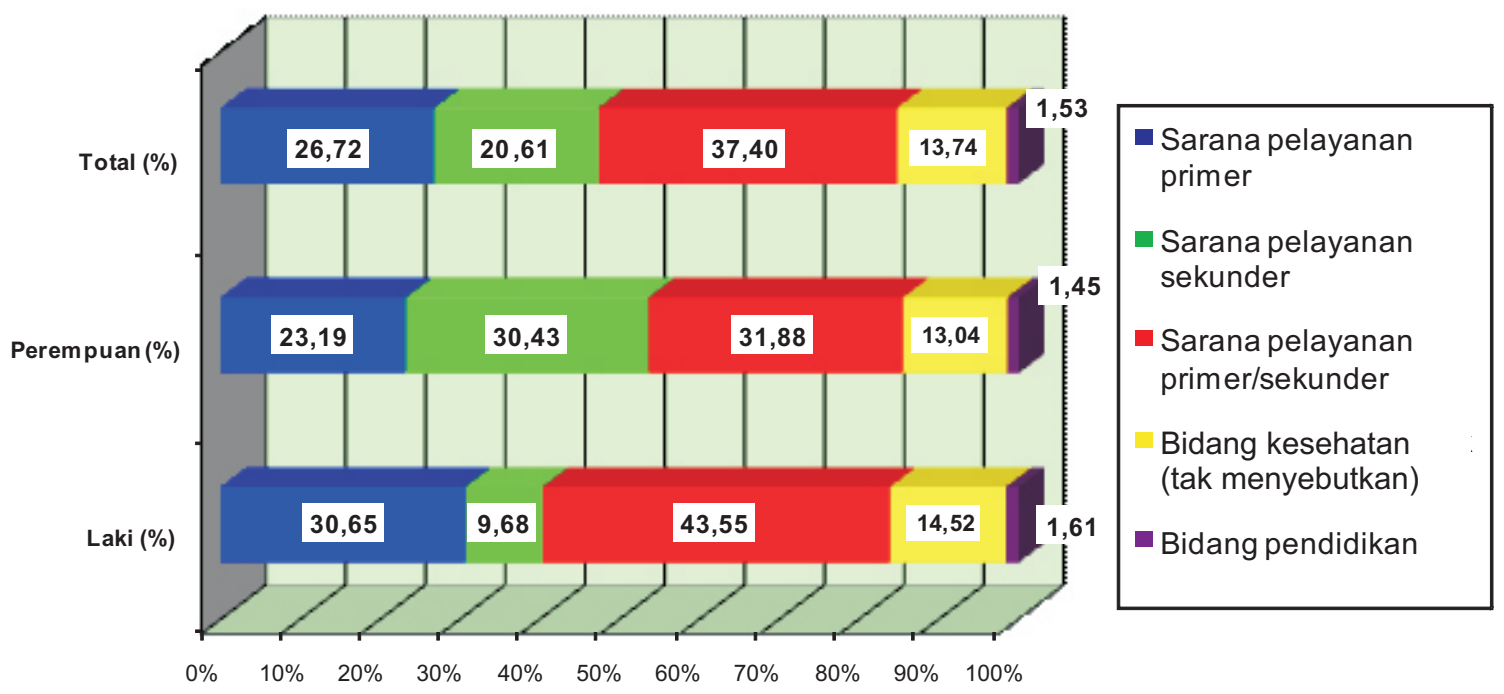

Gambar 6 Proporsi Rencana tujuan tempat bekerja setelah lulus dokter bagi peserta didik P3D Tahap 2 Fakultas Kedokteran Unpad tahun 2007

dibuka pendidikan magister-magister tersebut

Seperti yang telah dijelaskan pada awal, bahwa sebagian besar $(75,64 \%)$ peserta didik akan bekerja terlebih dahulu. Alasan peserta didik untuk bekerja adalah $35,18 \%$ responden menyatakan ingin mencari pengalaman terlebih dahulu. Selanjutnya $32,16 \%$ menyatakan ingin mengumpulkan uang terlebih dahulu sebelum melanjutkan pendidikan. Alasan lain yang cukup mengejutkan adalah sebanyak $13,57 \%$ peserta didik menyatakan bahwa menuntut ilmu di Fakultas Kedokteran melelahkan (capai), sehingga mereka ingin istirahat terlebih dahulu. Artinya untuk beberapa waktu mereka tidak mempunyai pendapatan (income) sendiri, kemungkinan masih disubsidi oleh keluarga.

Pada Gambar 5 terlihat bahwa hanya $31,62 \%$ peserta didik berencana untuk bekerja di Jawa Barat, sedangkan sebagian besar berencana bekerja di luar Jawa Barat.

Dalam penjabaran KIPDI III dan Standar Kompetensi Dokter tentu saja harus mempertimbangkan user dan lokasi tempat para dokter ini ingin bekerja. Pada Gambar 6 terlihat bahwa sebagian besar peserta didik berminat bekerja di bidang kesehatan dengan proporsi sebagai berikut: $26,72 \%$ di sarana pelayanan primer, $20,61 \%$ di sarana pelayanan sekunder, serta $37,40 \%$ di sarana pelayanan kesehatan primer dan sekunder.

Dari sarana pelayanan primer yang dipilih, sebagian besar $(42,86 \%)$ peserta didik memilih puskesmas sebagai tempat bekerja di sarana pelayanan primer walaupun hanya $36,84 \%$ laki-laki yang berminat bekerja di sini. Sebagian besar peserta didik laki-laki lebih berminat bekerja di klinik/klinik 24 jam/praktik sendiri. Sebaliknya, peserta didik perempuan lebih berminat bekerja di puskesmas. Hal yang menarik adalah adanya pilihan pekerjaan menjadi dokter perusahaan dan bekerja di LSM.

\section{PEMBAHASAN}

Dari 156 peserta pendidikan yang akan tinggal dan kemungkinan besar melanjutkan karir di Provinsi Jawa Barat dan Banten hanya sebesar $44,87 \%$, sedangkan sisanya $(55,13 \%)$ akan kembali dan berkarir di daerah asalnya masingmasing. Sebagai contoh adalah $26,92 \%$ berasal dari Jakarta dan hal ini dapat diramalkan bahwa mereka akan kembali bekerja di Jakarta. Hal ini sesuai dengan yang terlihat pada Gambar 5 bahwa hanya $31,62 \%$ peserta didik berencana untuk bekerja di Jawa Barat, sedangkan sebagian besar berencana bekerja di luar Jawa Barat. Ini juga berarti bahwa kontribusi Fakultas Kedokteran Unpad dalam menyumbangkan sumber daya manusia di bidang kesehatan untuk Jawa Barat hanya kurang lebih $30-40 \%$. Selanjutnya dari Gambar 2 terlihat bahwa sebagian besar peserta pendidikan lebih memilih melanjutkan sekolah ke jenjang yang lebih tinggi yaitu pendidikan spesialis atau magister. Informasi ini tentu saja mempunyai dampak yang sangat besar bagi user khususnya bagi kelangsungan pelayanan kesehatan di layanan primer. Para dokter tersebut sebetulnya tidak begitu berminat untuk hanya menjadi dokter di layanan primer dan akan bekerja di layanan primer bersifat sementara atau hanya untuk beberapa tahun, selanjutnya mereka akan melanjutkan pendidikan dan posisinya digantikan oleh lulusan-lulusan dokter baru. Siklus ini terus berlanjut dari tahun ke tahun dan terbukti dari hasil studi penelusuran dokter PTT dan dokter Pasca-PTT tahun 2004, hanya 22,1\% lulusan Unpad yang bekerja di Jawa Barat serta hanya $35,8 \%$ dokter berminat memperpanjang masa PTT. ${ }^{6}$ Kondisi ini akan mengakibatkan masalah yang besar antara lain: 1) terjadinya ketidaksinambungan program-program kese- 
hatan, 2) terjadinya hambatan dalam pencapaian cakupan-cakupan pelayanan kesehatan di layanan primer, 3) Inefektif dan inefisien dana untuk pelatihan, karena untuk satu topik saja dapat dilakukan pelatihan berkali-kali karena dokternya berganti-ganti.

Seperti yang telah dijelaskan pada awal, bahwa sebagian besar $(75,64 \%)$ peserta didik akan bekerja terlebih dahulu. Alasan peserta didik untuk bekerja adalah $35,18 \%$ responden menyatakan ingin mencari pengalaman terlebih dahulu. Selanjutnya $32,16 \%$ menyatakan ingin mengumpulkan uang terlebih dahulu sebelum melanjutkan pendidikan. Alasan lain yang cukup mengejutkan adalah sebanyak $13,57 \%$ peserta didik menyatakan bahwa menuntut ilmu di Fakultas Kedokteran melelahkan (capai), sehingga mereka ingin istirahat terlebih dahulu. Artinya untuk beberapa waktu mereka tidak mempunyai pendapatan (income) sendiri, kemungkinan masih disubsidi oleh keluarga. Pernyataan ini perlu mendapatkan perhatian baik bagi Perguruan Tinggi maupun user seperti Departemen Kesehatan, Dinas Kesehatan, Rumah Sakit, ikatan profesi, dan lain-lain. Bila instansi-instansi tersebut mewajibkan para dokter umum untuk meningkatkan profesionalismenya dengan mengikuti continuing medical education (CME) dan continuing professional development (CPD), maka sangat perlu dipikirkan sumber pendanaannya, karena para dokter umum ini belum tentu mempunyai dana untuk mengikutinya.

Pada Gambar 6 terlihat bahwa sebagian besar peserta didik masih berminat bekerja di bidang kesehatan dengan proporsi sebagai berikut: $26,72 \%$ di sarana pelayanan primer, $20,61 \%$ di sarana pelayanan sekunder, dan $37,40 \%$ di sarana pelayanan kesehatan primer dan sekunder. Pelayanan primer yang dipilih, sebagian besar peserta didik masih memilih puskesmas diikuti dengan klinik, praktik sendiri, dan ada pula yang memilih bekerja sebagai dokter perusahaan dan lembaga swadaya masyarakat.

Keadaan ini berimplikasi terhadap pengembangan kurikulum di Fakultas Kedokteran Unpad. Agar seorang dokter dapat bekerja di sarana pelayanan primer, maka prinsip-prinsip pelayanan primer ${ }^{7,8}$ harus dapat diakomodasi dalam kurikulum pendidikan antara lain:

Pelayanan kesehatan primer (primary health care) adalah pelayanan kesehatan yang sangat esensial dengan menggunakan ilmu kedokteran dan kesehatan praktis yang dapat diterima oleh individu, keluarga dan masyarakat, sehingga mereka dapat memelihara kesehatannya selama siklus hidupnya (every stage of their development). Pemeliharaan kesehatan ini dilakukan oleh masyarakat sendiri berdasarkan 2 prinsip yaitu tergantung dari diri sendiri (self reliance) dan pengambil keputusan sendiri. (self determi- nation). Untuk melaksanakan prinsip tersebut, maka sebagai dokter, kita harus melibatkan masyarakat secara aktif dan memberikan informasi kesehatan yang akurat.

Karakteristik pelayanan kesehatan primer adalah: 1) merupakan level pertama/strata pertama kontak dengan individu, keluarga dan masyarakat, 2) merupakan refleksi dan penerapan ilmu-ilmu (multidisiplin dan interdisiplin) sosial, biomedikal dan ilmu-ilmu lain yang terkait berdasarkan fakta (evidence), 3) menjadikan pelayanan kesehatan sedekat mungkin tempat tinggal atau tempat bekerja masyarakat, 4) melibatkan partisipasi masyarakat secara total agar mereka dapat menjalani dua prinsip yang telah dijelaskan sebelumnya. Ini sangat memberikan keuntungan bagi kita untuk menyelesaikan masalah kesehatan, tidak perlu setiap kali masyarakat harus mencari dokter, tetapi ada masalah yang mereka dapat pecahkan sendiri. Masyarakat di sini meliputi pula community workers seperti tokoh-tokoh masyarakat kader, dukun ataupun pengobat tradisional, 5) pelayanan kesehatan primer bukan suatu kegiatan yang berdiri sendiri, tetapi merupakan bagian dari Sistem Kesehatan Nasional. Pada Sistem Kesehatan Nasional ini terdapat pelayanan kesehatan sekunder dan tertier, ketiganya merupakan suatu kesatuan yang tidak dapat dipisahkan, dan 6) selalu memperhatikan masalah kesehatan utama yang terjadi di masyarakat, sehingga pelayanan kesehatan yang diberikan bukan saja bersifat kuratif dan rehabilitatif, tetapi meliputi pula preventif dan promotif,

Seperti yang telah diketahui bersama, dari seluruh populasi hanya $15 \%$ yang akan menjadi sakit, sehingga sesuai dengan amanat Deklarasi Alma Ata, maka bentuk pelayanan kesehatan primer utamanya menekankan upaya pencegahan agar masyarakat tidak jatuh sakit, selain itu masyarakat yang sehat dapat memelihara kesehatan secara optimal. Bentuk-bentuk pelayanan kesehatan primer minimal meliputi: 1) pendidikan kesehatan, agar masyarakat dapat mengatasi masalah kesehatan berdasarkan dua prinsip yaitu tergantung dari diri sendiri (self reliance) dan pengambil keputusan sendiri (self determination), 2) metode pencegahan dan pengendalian penyakit termasuk skrining penyakit, 3) nutrisi/gizi masyarakat, 4) sanitasi lingkungan dan suplai air bersih yang mencukupi, 5) kesehatan ibu dan anak termasuk keluarga berencana, 6) imunisasi penyakit menular yang dapat dicegah dengan imunisasi, 7) pencegahan dan pengendalian penyakit lokal dan endemis, 8) pengobatan rasional bagi penyakit dan kecelakaan (injuries), 9) ketersediaan obat-obat esensial.

Harapan lulusan dokter dari Fakultas Kedokteran Unpad adalah selain bekerja di 
layanan primer juga mampu menerapkannya dengan pendekatan kedokteran keluarga, sesuai dengan sembilan prinsip dokter keluarga yaitu $^{4,9,10}$

Seorang dokter keluarga terikat kepada individu bukan kepada penyakit yang diderita oleh individu tersebut. Bila dia tidak dapat menyem-buhkannya, maka dia berkewajiban merujuknya. Namun demikian ikatan terhadap individu ini terus berlangsung. Dia akan memantau perjalanan penyakitnya dan pengobatan di sarana rujukan. Hubungan atau kontak dengan individu ini juga berlangsung pada waktu individu tersebut dalam keadaan sehat. Artinya seorang dokter keluarga wajib memantau kesehatan dan melakukan upaya pencegahan.

Seorang dokter keluarga selalu mencari informasi untuk mengerti terjadinya suatu penyakit. Hal ini mengandung makna, bahwa tidak hanya informasi kedokteran saja yang diperlukan, tetapi informasi tentang faktor lain yang mempengaruhi terjadinya penyakit tersebut seperti lingkungan, sosial ekonomi, budaya dan lain sebagainya.

Seorang dokter keluarga menggunakan setiap kontak dengan pasien sebagai kesempatan untuk melakukan pendidikan kesehatan dalam rangka pencegahan penyakit (preventive medicine).

Seorang dokter keluarga melihat sasaran penduduknya sebagai population at risk.

Seorang dokter keluarga melihat dirinya sendiri sebagai bagian dari masyarakat, sehingga hal ini berimplikasi bahwa dokter keluarga harus dapat bekerja sama, berkoordinasi, dan berkomunikasi dengan seluruh masyarakat.

Seorang dokter keluarga sebaiknya tinggal di daerah tempat dia memberikan pelayanan kesehatannya, sehingga dia dikenal dengan baik oleh masyarakat tersebut.

Seorang dokter keluarga tidak hanya bertemu dengan pasiennya di tempat praktiknya, tetapi di tempat tinggal pasiennya. Mengetahui kondisi lingkungan tempat tinggal pasien, memberikan infomasi lengkap tentang kemungkinan faktor-faktor yang dapat mencetuskan timbulnya suatu penyakit pada pasien dan keluarganya atau tetangganya.

Seorang dokter keluarga sangat mementingkan aspek subjektif dari ilmunya.

Seorang dokter keluarga merupakan seorang manager yang mengelola sumber daya demi kepentingan pasien maupun masyarakat. Kesembilan prinsip dokter keluarga tersebut sebenarnya mempunyai arti sama yang dimaksud dengan prinsip pelayanan primer menurut International Conference on Primary Health Care, Alma-Ata, USSR, 6-12 September 1978, dengan demikian dapat disimpulkan bahwa dokter keluarga merupakan bagian yang tidak terpisahkan dari pelayanan kesehatan primer. ${ }^{11}$

Kesimpulan yang di dapat dari penelitian ini adalah ekspektasi peserta pendidikan lulusan Fakultas Kedokteran Unpad yang akan tinggal dan kemungkinan besar melanjutkan karir di Provinsi Jawa Barat dan Banten hanya sebesar $44,87 \%$, sedangkan sisanya $(55,13 \%)$ akan kembali dan berkarir di daerah asalnya masingmasing. Espektasi sebagian besar $(75,64 \%)$ peserta pendidikan lulusan Fakultas Kedokteran Unpad akan bekerja terlebih dahulu, namun selanjutnya sebagian besar $(97,46 \%)$ akan melanjutkan pendidikan spesialisasi $(81,69 \%)$. Baik peserta yang berencana langsung melanjutkan pendidikan maupun yang bekerja terlebih dahulu kemudian melanjutkan pendidikan sebagian besar memilih pendidikan spesialisasi, sebagian besar masih mencakup empat bidang utama yaitu ilmu penyakit dalam, ilmu bedah, ilmu kesehatan anak dan ilmu kebidanan diikuti dengan ilmu kesehatan mata dan ilmu kulit dan kelamin, Sebagian besar peserta didik berminat bekerja di bidang kesehatan dengan proporsi sebagai berikut: $26,72 \%$ di sarana pelayanan primer, $20,61 \%$ di sarana pelayanan sekunder, dan $37,40 \%$ di sarana pelayanan kesehatan primer dan sekunder. Puskesmas masih dipilih sebagai tempat kerja diikuti dengan klinik, praktik sendiri, dan ada pula yang memilih bekerja sebagai dokter perusahaan serta lembaga swadaya masyarakat.

Fakultas Kedokteran Unpad perlu memberikan prioritas kepada calon mahasiswa yang berasal dari Jawa Barat agar dapat berkontribusi dalam memenuhi kebutuhan dokter di Jawa Barat.

Perlu pengembangan kurikulum pendidikan dokter agar lebih menarik, sehingga para calon dokter ini bersedia untuk tetap bekerja di sarana pelayanan kesehatan primer.

\section{DAFTAR PUSTAKA}

1. World Health Organization, The World Health Report 2002, Reducing risks, promoting healthy life. Geneva: WHO Library; 2002.

2. Departemen Pendidikan Nasional. Kurikulum Inti Pendidikan Dokter Indonesia (KIPDI) III, 2004.

3. Konsil Kedokteran Indonesia. Standar Kompetensi Dokter. Jakarta Selatan: Konsil Kedokteran Indonesia; 2006.

4. McWhinney, Ian R. A textbook of family medicine. Second edition. New York: Oxford University Press; 1997.

5. Dinas Kesehatan Provinsi Jawa Barat. Profil Kesehatan Provinsi Jawa Barat, 2007.

6. Dinas Kesehatan Provinsi Jawa Barat bekerjasama dengan Unit Penelitian Kesehatan Fakultas Kedokteran Universitas Padjadjaran. Studi penelusuran Dokter PTT dan Dokter Pasca PTT di Jawa Barat, 2004. 
7. World Health Organization. Alma-Ata, primary health care. Geneva: WHO; 1978.

8. Walt G, Rifkin S. The political context of primary health care. Dalam: Streefland P, Chabot J, penyunting. Implementing primary health care, experiences since Alma-Ata. 1990, h. 13-20.
9. Rakel RE. Textbook of family practice. Edisi ke6. Philadelphia: WB Saunders Co; 2002.

10. Lee Gan, Azwar.A, Wonodirekso. Family medicine practice. Singapore: 2004.

11. Departemen Kesehatan RI. Sistem Kesehatan Nasional. Jakarta: Dep Kes RI; 2004. 